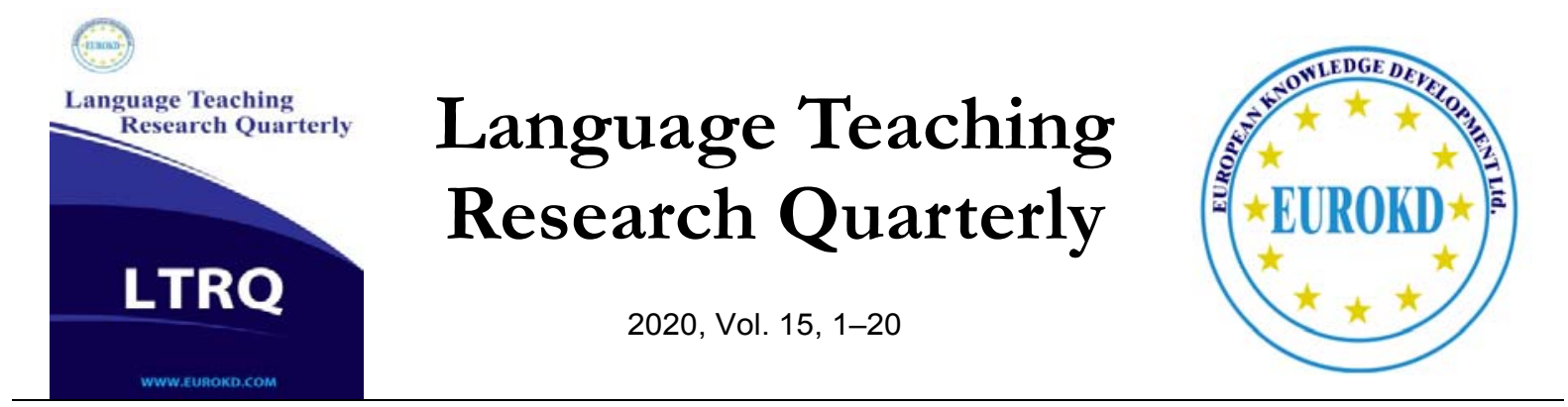

\title{
Is Materials Development Progressing?
}

\author{
Brian Tomlinson \\ University of Liverpool, Anaheim University, Shanghai International Studies University, UK \\ Future Perspectives and Challenges of Materials Development \\ In Honor of Brian Tomlinson's Contribution to Materials Development Research
}

Received 21 September 2019 Accepted 29 November 2019

In this article I am going to review the 'progress' which L2 materials development has made both as a practical pursuit and as an academic discipline since my first contact with materials development in the 1960s. I am also going to evaluate the current situation, to make predictions about future developments and to make recommendations to teachers, to materials developers, to researchers, to publishers and to Ministries of Education. As I have reviewed the 'progress' of materials before (in, for example, Tomlinson (2012); Tomlinson \& Masuhara (2013); Tomlinson \& Masuhara (2018)) my review will be brief and my main emphasis will be on my evaluation and recommendations.

\section{The 'Progression' of Materials Development}

\section{The Beginning}

I first became involved in materials development in 1965 when I was working as a VSO (Voluntary Service Overseas) in The Advanced Teachers' College in Owerri, Nigeria. I was given a coursebook and told to teach from it. The unit I was told to start with was so boring and irrelevant to the students that they were likely to fall asleep in the mid-morning heat. The reading passage was about "Eskimos" building igloos in the Arctic and the instruction to the students was to read it carefully and then answer the questions after it. I decided to try and relate it to the 
students' lives before asking them to read it and I started the lesson by asking them how many lived in villages. They all did (or had family who did). I asked them how they built their homes in the villages and they told me about going into the forest to get wood and leaves and other materials they needed. They also told me they revisited the forest when it was time to rebuild their homes. I asked them to imagine what it was like to live in a place where there were no trees and only snow on the ground. I also asked them to guess how the people who lived there built their homes. Then I told them to read the passage and see if their guesses were right and to think about all the similarities and difference between how they built their homes and how the "Eskimos" did. Afterwards we discussed their responses. I did not realise it at the time but I was participating in materials development. I was adapting the materials I was given to make them more meaningful and more cognitively and affectively engaging for the learners (principles I now consider fundamental not just for materials but for all aspects of second language acquisition (Tomlinson 2016). Over fifty years later teachers are still engaged in the same activities, adapting materials to make them more relevant and rewarding for their learners (see Harwood (2014), Garton \& Graves (2014), McGrath (2016) and Tomlinson \& Masuhara (2018)).

My second involvement with materials development came at the Institute of Education, the University of London when I had returned from Nigeria and was studying for a PGCE in ESL. Materials development played a small part on the taught course and consisted mainly of looking at examples from the coursebook our lecturer had published and being encouraged to adopt a bits and pieces eclectic approach to developing our own materials, with the emphasis being firmly on teaching discrete items of grammar through the provision of controlled and guided practice in quirky situations. What I remember most vividly though are my attempts at developing materials to use during teaching practice. I taught first in a secondary school in Bethnal Green and was told by my mentor to just get the students to read aloud from the coursebook and to not try anything clever. Not being able to face the torture of listening to endless droning I tried something clever, took the class to the gym, instructed them to use the drama materials I had recklessly devised the night before and which were then responsible for the chaos and destruction which ensued. My second teaching practice was with a group of young Asian boys who were being given a crash course in English before being admitted to mainstream classes in a secondary school in Luton. Of course there were no materials available so I developed an innovative, though now rather embarrassing, course, in which the boys were filmed doing things on the streets of Luton and playing football in the playground. We then watched the films in the classroom whilst the boys took it in turns to give commentaries in specified tenses (e.g. One boy gave a here and now commentary in the present tense and then the next boy gave a past tense commentary on the same film). This approach did feature such pre-requisites of second language acquisition as recycling, personal relevance, meaningfulness, bizarreness and contextualisation but (like most materials of the day) it did little to facilitate development of interactive competence and it was rather monotonous. For my third teaching practice I taught young adults in a language school in Soho. Most of the students were striptease artists earning money in nearby clubs whilst learning English. Sometimes they disappeared in the middle of lessons to go and perform their acts but 
we had great fun laughing and joking together and performing the bizarre drills which I devised to provide fun practice in 'using' structures. I remember one drill quite vividly in which students 'flew' around the classroom as Billy and Bessie Bee enjoying an innocent romance whilst illustrating prepositions by landing on tables and windows, hiding under chairs and in bins and flying into empty boxes. My materials for all three teaching practices were developed intuitively and were eclectic and variable in their underlying principles. I learned a lot from teaching practice (especially the importance of engaging the learners and the dangers of incoherent eclecticism) but I am not so sure my students did. Over fifty years later many teachers and coursebooks are still predominantly intuitive and eclectic (Prowse, 2011) and there is little evidence of the principled, systematic approaches to materials design which I have advocated in, for example, Tomlinson (2011, 2013a, 2013b, Tomlinson 2016) and Tomlinson and Masuhara (2018).

My first significant involvement with materials development came in 1969 at the then Mankoya Secondary School in Zambia, where Rod Ellis and I got bored with the coursebook we were supposed to use and together wrote materials for our lessons. Our material seemed popular with our students so we submitted it to Longman Zambia and not much later it was published as Situational English Books 1-3 (Ellis \& Tomlinson, 1973). Then it was adapted by the Ministry of Education as the national coursebook for government secondary schools. That was how coursebooks got developed and published in those days. Not anymore. Nearly fifty years later publishers do not typically consider proposals for coursebooks. Instead they identify a gap in the market or decide to clone a commercially successful coursebook, specify a syllabus and an approach and then hire writers to deliver the materials to order.

Enough about me. What about what other people were doing in the sixties and early seventies? Most teachers were teaching mainly from coursebooks (as they still are today according to my experience observing classes and to research by the British Council (2008), by Tomlinson (2010b), by Saw (2016) and by Tomlinson \& Masuhara (2018)), and the coursebooks were focusing mainly on the teaching and practice of grammatical structures (as they still are today). The coursebooks claimed to follow the principles of approaches such as the direct method, the audio-lingual method and then the situational approach but most of them (including Ellis \& Tomlinson (1973)) followed a procedure (as most coursebooks still do today) which came to be known as Presentation, Practice, Production There were attempts though to relieve the monotony of constant practice through the use of humour, bizarrness and narrative, attempts unfortunately not always made today.

Materials development tended to be referred to in pedagogic books as materials writing and was typically allocated brief sections in books on methodology (e.g. Moskowitch, 1978; Richards, 1978). It was certainly not considered to be an academic discipline.

\section{What Happened Next?}

In Tomlinson (2012) and Tomlinson and Masuhara (2018) I have detailed what happened with regards to materials development in the 1980 s and 90 s so I will just make a few comments here. 
It was quite an exciting time for materials development as a practical pursuit with the communicative approach pushing publishers to focus more on communication and slightly less on grammar and with the functional/notional approach stimulating experiments with coursebooks focusing on the development of pragmatic competence for the first time. However the pedagogic approach remained PPP, with structures, functions, notions and vocabulary being introduced explicitly, practiced deliberately and then produced in restricted situations. Even so there was a backlash towards the end of the century, the communicative approach was blamed for a conveniently perceived increase in erroneous production and there was a gradual return towards the centrality of grammar.

In the 1980s there some publications focusing on materials development (for example, Cunningsworth (1984) and Sheldon (1987) with their emphasis on materials evaluation) but materials development did not become recognised as an academic discipline until the 1990s, although even then it was still considered to be a theoretical (Graves, 2019). In 1993 I founded MATSDA (www.matsda.org) to bring together teachers, writers, researchers and publishers with the objective of improving materials development as a practical pursuit through conferences, workshops, competitions and a journal called Folio. In 1994 I developed and led an MA in L2 Materials Development at the then University of Luton and in 1995 Hidalgo, Hall and Jacobs edited a book of chapters by materials writers on the process of materials writing. In 1998 I published a book of chapters which linked theory to practice in order to make suggestions for the improvement of materials for language learning and then came similar books by McGrath (2002), Mukundan (2003) and Tomlinson (2003). Materials development gained greater respect as an academic discipline, MA course designed modules on it, $\mathrm{PhD}$ students and university researchers started researching it, conferences were held on it, more and more articles and books were published on it and materials development progressed towards its current status as an academic subject worth researching.

\section{Materials Development in Practice Today}

One thing that has definitely not changed is that materials development as a practical pursuit can be in design, as designed, in action or in reflection. Each of these stages is inevitably different with the realisation of the concept of a set of materials changing as challenges are encountered, constraints are imposed and feedback is provided. The result is that the final product is typically very different from how it was originally envisaged. In my experience (and especially recently) the final product (i.e. the materials as designed) often resembles already existing materials more than it does the innovative concept, as the commercial caution of the publishers and the conservatism of advisors sift out the unfamiliar. The final product is then distributed and used by teachers with learners in ways which differ from classroom to classroom depending on beliefs, personalities, restrictions, time constraints, objectives, interference and preferences. The product is also used differently by each learner with some memorising sections of it, some using it for revision, some using it as a stimulus for supplementation and all giving attention to what appeals to them. The product also changes in reflection, with its users representing it differently in their 
minds. Some things are remembered and some forgotten, some things are represented negatively and some have positive associations. Everything which remains from the product is remembered in connection with how it was experienced. As we will see in the section on materials development as an academic discipline below there has been considerable research on materials development in design and as designed and a lot of research is now being conducted on how teachers use materials (materials in action). However I know of no research on how learners use materials (materials in action) nor on how teachers and learners represent materials which they have used (materials in reflection). I am hoping that we will know much more about this in the future, a future when maybe learners will design, use and reflect on their own materials at the same time individually or in groups.

\section{Commercial Publication}

In surveys of coursebooks which I have been involved in (Tomlinson et al., 2001; Masuhara et al. 2008; Tomlinson \& Masuhara, 2013)) it was found that despite changes in the wording of blurbs, the use of buzz words such as natural approach, functional/notional approach, communicative approach, task-based and CEF capabilities and the design and lay-out of books, the dominant methodology of coursebooks has remained Presentation, Practice, Production (PPP). In mini-analyses of units in coursebooks for Tomlinson and Masuhara (2018) and for Tomlinson and Masuhara (forthcoming) and in recent classroom observations in England and in China I have found the situation to be the same today. In Tomlinson and Masuhara (2013) we welcomed the greater encouragement of learner-learner interaction and the greater personalisation of activities and I still do so today, with most books now frequently asking learners to share their experience and their views. I also notice though, with some regret, an even greater proliferation of expensive extras, with Headway Pre-intermediate (Soars \& Soars, 2012), for example, offering a student's coursebook, workbook with iCheckerCD-Rom and website as well as a teacher's book, class audio DCs, itools for the digital classroom and teacher's website. I am even more disappointed to see that commercial coursebooks continue to ignore much of what we have learned from second language acquisition research (SLA) and that they persist in:

- focusing on the explicit learning of language forms (thus helping learners to communicate accurately in planned discourse but not helping them to communicate effectively in unplanned discourse);

- assuming that explicitly learned declarative knowledge can be transformed into implicit procedural knowledge through presenting a language feature, getting learners to practise it and then getting them to use it in contrived and simplified situations;

- using listening and reading to focus on language forms;

- asking closed questions and setting closed activities (thus restricting peer interaction and the expression of ideas and opinions (Freeman, 2014; Tomlinson, 2018));

- ignoring such pre-requisites for language acquisition as providing a rich, meaningful and recycled exposure to language in use, engaging learners cognitively and affectively, providing learner choice, encouraging learner noticing and discovery, encouraging 
learner experience of the language outside the classroom and providing opportunities for authentic communication (Tomlinson, 2011, 2016; Tomlinson \& Masuhara, 2018, forthcoming);

- ignoring the potential of such experiential approaches as task-based approaches, textdriven approaches and CLIL approaches.

What I say about coursebooks above also seems to be true of digital materials, with many of them ignoring the possibilities offered by the medium of authenticity of text and task, recycling, individualisation, choice, localisation, exploration and contextualisation and often offering little more than typical coursebook closed activities in a possibly more attractive, navigable and easily accessible way. For a critique of digital materials see Tomlinson and Masuhara (2018).

So it seems there is an apparent lack of progress towards matching coursebook development with what we know can facilitate the development of communicative competence. If this true is true, we need to ask what factors are contributing to what seems to be unprincipled practice.

From my many years of submitting proposals to publishers, working as an advisor and as a writer for publishers, leading materials development projects and working as a teacher, teacher trainer and academic in many countries around the world I would say that the following are some of the reasons why commercially published materials have not progressed since I started my career:

- Publishers are working more and more to a profit driven imperative and to urgent deadlines, and seem to no longer have the time (or the inclination?) to listen to and to give conference presentations, to read and to write articles, chapters and books or to apply recent findings from, for example, corpus linguistics, pragmatics research and neurolinguistics to their publications. When I founded MATSDA (the international Materials Development Association) in 1993 many publishers attended our conferences, gave presentations, took part in debates and wrote articles for our journal Folio. For many years now we have had no contributions from publishers. They say they are too busy.

- Because of the massively increased cost of developing a series of coursebooks and of the profit driven imperative mentioned above publishers cannot risk publishing innovative materials. They continue to publish coursebooks which achieve face validity by looking just like previously popular coursebooks and, in fact, even research what makes a commercially successful coursebook popular and then clone those features. I have actually (to my eternal shame) conducted such research for a very famous publisher.

- Publishers appear to either clone commercially successful coursebooks or make use of market research (not SLA research) to identify gaps in the market. This means that they very rarely consider proposals from materials writers but rather establish the syllabus and approach for a new course and then recruit writers to develop materials to their prescription. This inevitably inhibits innovation. For example, the Action-Oriented Approach has, according to Piccardo \& North (2019), been accepted in language education as a research-informed approach since the beginning of this century. This is an 
approach in which the learners are actively engaged in performing real world, contextualised tasks with practical outcomes (e.g. organising a meeting; designing an advert; producing a timetable). We did publish a coursebook based on such tasks for the Ministry of Education in Vanuatu (Tomlinson, 1981) but I have yet to see this approach have any impact on the design of global coursebooks.

- There are pragmatic reasons why publishers resist some innovations. For example, I have had experience of publishers being reluctant to use authentic materials because of the cost and difficulty of getting permissions and understandably no commercial publisher will risk including such controversial topics as alcohol, politics, religion, history or sex in a coursebook because of the risk of giving offence.

- The writers who are recruited to write (rather than develop) coursebooks to prescription tend to be young, inexperienced and keen to break into the field. They often have limited awareness of research with the potential for practical application and even if they do they are understandably reluctant to risk challenging the publisher or introducing innovation.

- Even if publishers do consider a proposal for a course they are highly unlikely to accept it if it differs from the expected norm. I had recent experience of this when my proposal for a research informed, blended course was politely not taken forward by a major commercial publisher. The course followed a text-driven approach (Tomlinson, 2013b) in which potentially engaging authentic texts drove activities in which the learners, for example, responded personally to a text, developed a related text themselves, made discoveries about how language was used in the core text and then revised their own text. This is an approach I have used and seen used successfully all over the world but it was considered by the publisher too daunting and demanding for the learners and teachers in their markets who were used to a structured approach. Who can blame the publisher for not taking a potentially disastrous risk? But then if no risk is taken no potentially valuable application from research will ever be made and researchers will continue to claim they have made a contribution to the field when no impact at all on the typical classroom has been made.

- Publishers do try to keep up by conducting their own research. For example, Cambridge University Press have a Language and Pedagogy Research Unit which has produced a series of online Cambridge Papers in ELT with reference to research and suggestions for application to practice (https://languageresearch.cambridge.org/cambridge-papers-in-elt). I am not sure though how many suggestions the publishers actually follow though when it comes to the risky business of publishing coursebooks.

- High stakes examinations resist anything more than cosmetic change because of their need to be able to assess and mark huge cohorts from around the world efficiently and reliably. To achieve reliability they need (or think they need) to use such objective means of measurement as multiple choice questions, Yes/No questions, matching, sentence combination, sentence completion and $\mathrm{C}$ tests. High stakes examinations thus have negative backwash effects on curriculum development, classroom pedagogy, classroom 
testing and, unfortunately, language learning materials. When I was a chief Examiner in Vanuatu I managed to change the examinations from discrete item tests of declarative knowledge to task-based tests of communicative ability. Almost overnight the classroom pedagogy changed and we developed and published task-based materials which could be used as classroom tasks or as assessment tasks.

- Ministry of Education officials, inspectors, principles and heads of department are typically conservative when it comes to recommending or purchasing coursebooks. If they take a big risk and it goes wrong their careers are at stake. So they are more likely to approve materials which achieve face validity by conforming to expectations, thus perpetuating the status quo.

- Many potentially valuable reports of research which could usefully be applied to materials development are not accessible to teachers and materials developers. Either they are in journals which are not known or available to practitioners or they are written for fellow researchers with prior knowledge of the field and competence in understanding its jargon.

While the product of commercial publication seems to have undergone little change the process of publication seems to have changed dramatically. In the past, teachers and materials writers submitted proposals with an outline of the course plus sample materials. If a proposal was accepted draft materials were written, feedback was provided by editors (and sometimes by reviewers), the materials were revised and then often the revised materials were piloted in classrooms and revised again before publication. The writers were paid royalties (usually 10\%) and they could make a lot of money if a course was successful. This was a great incentive for experienced and talented teachers to devote time to the design and delivery of a coursebook (or a supplementary book) which was different from others on the market. Nowadays publishers commission coursebooks instead of responding to proposals. They establish an approach and framework, they formulate a syllabus, they develop a scope and sequence and then they hire writers to write materials to prescribed specifications for a fee. There is no time for piloting, with focus group feedback and questionnaires often having to suffice as a means of providing feedback prior to revision and publication. Huge sums of money are invested in the publication of a coursebook with most of it seeming to go on design and promotion and little of it on rewarding the writers (Graves, 2019). No wonder there seems to be little evidence of innovation, creativity or energy in many recent coursebooks with such a lack of incentive to invest time and energy and with little opportunity or permission to try out something new. Have a look at a number of recently published coursebooks and you will see how similar they are, with some books seeming to be cloned from those most commercially successful in the field.

For a comparison of the old and the new ways of publishing a coursebook compare Donovan (1998) with Amrani (2011) and for descriptions of how coursebooks are typically published see Singapore Wala (2003, 2013), Aitchinson (2013), McGrath (2013), Zemach (2018) and Tomlinson and Masuhara (2018, Chapter 6 - The Process of Publishing Coursebooks). One thing 
that seems to have remained the same is that specifying the SLA principles to be applied and the principled criteria to be used in monitoring and evaluation are stages in the design of courses which are conspicuously missing. What matters most is market research not SLA research. If the application of a principle could help a coursebook to achieve greater facilitation of language acquisition for its users but at the same time limit the number of sales of the book then I have to admit it would be reckless to apply it. This is not a criticism of publishers but an acknowledgement of a reality. If I was a publisher my main concern would be making a profit too.

We cannot expect publishers to take risks on innovation. If we want to see changes in commercial materials development we need to demonstrate that research informed, innovative materials can be designed and promoted in ways which appeal to the market. If an informed risk was then taken and the product not only helped learners develop communicative competence but made the publisher profits too then change at last would be on its way.

\section{Materials Development Projects}

In my experience most of the principled innovations in materials development have taken place on materials development projects undertaken by institutions or by ministries of education rather than in published materials. Often the driver of such projects is dissatisfaction with the materials in use, whether they be global coursebooks or local coursebooks developed by overseas publishers which do not sufficiently cater for the needs and wants of local students or locally produced materials considered to be out of touch with modern developments. Many of these projects are innovative but unfortunately most of them are not reported on in journals and their effects are often not researched. In addition many of them are dependent on the vision and energy of individuals and their impact is not sustained when these individuals move on. This is what seems to have happened on the PKG Project in Indonesia, a project whose Bahasa Indonesia motto translates as 'For the teacher by the teacher'. As Leader of the PKG English Program (Tomlinson, 1990) I trained 97 secondary school teachers of English teachers as teacher developers and then they trained key teachers in their provinces while I travelled the country monitoring and supporting the project. Decisions about methodology were made by the teacher developers and materials were written, revised and used by teams of teachers from adjacent schools. A comprehension approach was followed in which the initial focus was on meaning and understanding rather than on form and production. A TPR Plus approach (Tomlinson, 1994) was used for the first thirty hours in experimental classes throughout the country in which students mimed stories told by their teacher, made meals from instructions given by their teacher, played games from instructions, painted murals from instructions and hunted treasure from clues given by their teacher. Gradually reading was introduced through extensive readers in which $50 \%$ of the content words were 'good friends' sharing pronunciation or spelling with equivalent words in Bahasa Indonesia and then the students started speaking in task-based activities when they were ready to do so. One of the teacher developers evaluated the programme for his $\mathrm{PhD}$ and found 
that attendance was dramatically higher for students in the experimental classes and that they outperformed students in the conventional classes on the end of year Ministry of Education examinations. Unfortunately the thesis is no longer available and even more unfortunately I left the programme after three years and the dynamic Indonesian leader of the PKG Project died a few years later. When I visited Indonesia recently the schools and the materials seem to have reverted to a grammar centric PPP approach with teachers complaining that very few of their students could communicate in English.

Despite what seems to have happened (or rather not happened) to the PKG Project I still think our main hope for real progression in materials development lies with projects in which the main goal is to help learners to develop communicative competence rather than to make financial profit. Certainly the only real advances in materials development I have seen in action have been achieved on projects I have been involved in or have been made aware of. For example, a Namibian secondary school coursebook (On Target, 1994) was developed by a group of thirty teachers following a text-driven approach. Then a Norwegian secondary school coursebook Search (Fenner \& Nordal Pedersen, 1999) was based on the approach used in On Target. It was notable for its use of world literature and aesthetic illustration and was the best coursebook I have ever seen. Other principled and innovative materials development projects I have been involved in have been a text-driven language improvement course for Ethiopian primary school teachers, a course for Bulgarian schools which focused on a brother and sister from England staying with and communicating with a family in Bulgaria, a story-driven coursebook for Chinese primary students and a text-driven coursebook for Singapore secondary students. Some of these projects had to make compromises but they remained principled and were at least different from the predecessors. For descriptions of some of these projects see Tomlinson (1995) and for accounts of other innovative materials development projects see Popovici and Bolitho (2003) and Bolitho (2008).

\section{Materials Development as an Academic Discipline Today}

As well as being the practical undertaking described above materials development has progressed in the last twenty years as popular field of academic study which investigates the principles and procedures of the design, writing and implementation of materials, as well as the effects which materials have on their users. Ideally materials development as a practical undertaking and materials development as an academic discipline 'are interactive in that the theoretical studies inform, and are informed by, the actual development and use of learning materials' (Tomlinson, 2001, p. 66). Many recent academic publications about materials development have attempted to achieve such an interaction, for example Garton \& Graves (2014), Harwood (2010, 2014), Masuhara, Tomlinson \& Mishan (2016), McDonough, Shaw \& Masuhara (2013), Maley \& Tomlinson, (2017), McGrath (2013, 2016), Mishan \& Timmis (2015), Mukundan (2008), Tomlinson (2003, 2008a, 2010a, 2011a, 2013a, 2013c, 2016a) and Tomlinson \& Masuhara $(2010,2018)$. Nearly all the writers in these books are both practitioners 
and researchers and they have developed or reported theoretical principles in an attempt to achieve a positive influence on the practical processes of materials development.

There has also been considerable progress in terms of materials based research since the nineteen nineties with the most impressive phenomenon being the growth of materials driven research which is conducted and reported in order to inform and influence teachers and teachers in training. The result has been applyable research reported in accessible publications and conference presentations. Journals which used to focus on practical suggestions for the classroom and occasionally on ideas for materials (for example, Language Teaching Professional, Modern English Teacher, the English Teacher, TESOL Journal and, especially, ELT Journal) now frequently focus on materials development and report practice driven research in articles which are accessible and potentially useful to teachers and teachers in training. For example, in ELT Journal, Volume 73, Issue 3, July 2019 two of the eight articles report materials development research and there is a survey of 'Recent books on language materials development and analysis' by Kathryn Graves (pp. 337-354). In addition, conferences for teachers (such as IATEFL, TESOL, the JALT Conference in Japan and the RELC Conference in Singapore) which used to focus in their presentations on either pedagogic theory or practical suggestions for classroom methodology now often feature reports on practice driven research on materials development and use. Such reports are now also a feature of journals dedicated to materials development for language learning such as Folio (the journal of MATSDA, the international Materials Development Association) and Between the Keys (the official newsletter of the JALT Materials Writers SIG) and at conferences focusing on aspects of materials development and use (for example, the annual MATSDA Conference (www.matsda.org), a recent RELC Conference focusing on materials development and recent major conferences in Chile and Malta with materials development strands). Also in the last ten years there have been a number of books devoted to bridging the gap between theory and practice in materials development and these have included numerous chapters reporting practice driven research in language which would be accessible to teachers and researchers alike and with suggestions for applications of research and theory to practice. Such books have included Tomlinson \& Masuhara $(2010,2018)$, Tomlinson (2013, 2016), McGrath (2013, 2016), Harwood (2014), Garton \& Graves (2014) and Azarnoosh et al. (2016).

The main focus of the materials development research referred to above has been on the application of research-informed principles to the design, evaluation and adaptation of materials. Currently the focus seems to have switched to the use of materials in the classroom, and in particular to what teachers actually do and get their students to do with language learning materials in the classroom. This is the main concern for example of a new international research group called MUSE, (Materials Use in Language Classrooms) which conducts classroom based research and reports it in meetings and publications (see https://museinternational.wordpress.com/) and of such publications as Garton and Graves (2014), Harwood (2014), McGrath (2016), Tomlinson and Masuhara (2018) and Graves (2019). The cultural content of coursebooks is another current focus of research with a number of analyses 
revealing a prevalence of cultural stereotypes and a bias towards a representation of middleclass, affluent, successful, neo-liberal and capitalist people and values. For critical analyses of the cultural content of coursebooks and the resultant effects on learner perceptions see Gray (2012). Holborrow (2015), Block (2017), Bori (2018) and Risager (2018).

What I have reported above is all good news and represents considerable progress. However there are danger signs that materials development research is becoming more theory driven and academic, thus making it less accessible and applyable for practitioners. Exclusive jargon is being coined and used to report common classroom and learning phenomena, publications are becoming dominated by statistics and a requirement to demonstrate reliability and empirical evidence is becoming a prerequisite for publication. If we are not careful materials development research might soon match Alan Maley's evaluation of the value of academic research for teachers as having 'relatively modest value for teaching and learning : the quantity and sheer inaccessibility of data, the relative lack of its real relevance for teaching, the paucity of useful results despite massive investment of time, effort and money, the triviality of much 'research'. especially when carried out as a higher degree requirement, the difficulty of conducting reliable research, the fact that even helpful research findings are routinely ignored, and the fact that most advances and new ideas within language pedagogy do not have their origins in research anyway.' (Maley, 2016).

\section{The Future of Materials Development}

There is a big difference between what I expect to happen in the future and what I would like to happen in the future.

\section{What I Would Like to Happen in the Future}

I would like commercially published materials to make much more use of such research informed experiential approaches as the text-driven approach, task-based approaches and CLIL approaches and to be much less reliant on restrictive and discrete item focused PPP approaches. I would also like such materials to use far more open-ended activities which stimulate thought, creativity, expression of ideas and opinions and interaction with peers and to stop being dominated and restricted by closed activities which are easy to mark but contribute very little to the development of communicative competence (Tomlinson, 2018).

I would like materials to be developed on the assumption that they will inevitably need to be adapted in order to meet the needs of particular learners, with particular needs, wants and experience in particular learning situations. Such an acknowledgement could lead to activities being developed so that they could easily be personalised and localised by teachers and learners, to menus of texts and activities being offered for teachers and learners to choose from and to suggestions for teachers to help them make principled adaptations to the materials.

I would like materials to be developed which acknowledge the reality that learners need to spend far more time experiencing their target language in actual use than studying it or practising it at a desk and that materials should be designed as a starting point and as a stimulus to look out 
for the language in use outside the classroom. Such materials could make use of blended learning, of web links and of projects and activities which start in the classroom but continue outside it (e.g. researching the actual use of a structure focused on in the materials).

I would like materials to be developed which reflect the world as it actually is rather than portray the idealised, sanitised, harmonious, healthy, capitalist, middle-class, conservative and affluent world which it is implied learning the language provides access to.

I would like research to be conducted on the actual effects of different types of coursebook activities and approaches on the development of communicative competence and their findings then applied to the development of materials. These studies would need to be longitudinal and large and it would be very difficult to isolate variables and to demonstrate cause and effect. Nevertheless such research could discover strong tendencies (as opposed to absolute proof) and beneficial developments could take place. And, in any case, where is the empirical evidence that approaches and activities which currently dominate published materials have beneficial effects on the development of communicative competence?

Above all I would like initial and in-service teacher training courses to focus on materials development (after all materials tend to dominate and dictate what happens in the classroom) and in doing so to invite trainees to develop principals and criteria to use to critique existing materials, to adapt materials and to develop materials of their own (for a report on the value of such courses see Tomlinson (2014b) and for books written for use on such courses see Tomlinson \& Masuhara (2004) and Tomlinson (2019)).

The developments I wish for above could happen but only if teachers were better informed about the findings of SLA research, if teachers were encouraged and helped to do action research in their classrooms, if teachers took action to make publishers aware of what changes they would welcome, if researchers focused on making discoveries which could be beneficial to learners rather than on measuring the measurable and achieving academic acclaim, and if publishers were convinced that changes could be profitable for them as well as for teachers and learners.

I am not optimistic.

\section{What I Think Will Happen in the Future}

Given the economic imperative which drives commercial publishing, the inherent conservatism which drives government decisions and the ever prevailing conviction that you need to study a language in order to acquire the ability to use it, I am not optimistic that there will be many positive changes in the future to how language learners are influenced to try to learn a language. I think that the use of digital materials will increase both in the classroom and in the home and that this might provide more opportunities for learners to experience contextualised and embodied use of the their target language. I also think there will be a recognition of the fact that the needs and preferences of language learners are becoming increasingly diverse and that more needs to be done to cater for this diversity. However I also think that the need for commercial publishers to gain profitable returns on their investments and the need for governments to restrict 
spending and to achieve standardisation and conformity will mean that learner choice and individualisation will remain restricted.

I hope that I am wrong but I think that the focus on explicit teaching of language forms will continue to dominate materials development. Publishers will only publish what their market research indicates they will be able to sell and no publisher is going to risk huge losses by taking a chance on research informed material which is radically different from what the market expects. At the same time high stakes examinations (and therefore all examinations) are going to continue to assess language learners in ways which are quick, cheap, easy and reliable to mark and the focus will remain on accuracy.

So my vision of the future is a rather pessimistic one in which PPP prevails and throughout the world most language learners continue to get bored, frustrated and fail. But enough learners will be sufficiently motivated and affluent to gain opportunities for travel, experience, exposure and use, and communication will continue to be achieved. Maybe that is what governments, language schools and publishers actually need. If, for example, most of the learners in all the secondary schools in a country succeeded in acquiring communicative competence in English, then the social and economic stability of the country could be at risk. And, if most learners of a language were soon successful then fewer materials and fewer lessons would be needed and less money would be made.

\section{My Recommendations}

In order to try to prevent my pessimistic vision of the future coming true I would like to make recommendations which I hope are sufficiently realisable to be at least considered.

\section{My Recommendations to Publishers}

I would recommend in-house development courses on which all personnel involved in the publication of language learning materials are made aware of the findings of second language acquisition research and of their possible application to the development of materials. These courses should be experiential and should involve critical evaluation of the research findings and of suggestions for their application, analysis and evaluation of published materials, the creation and evaluation of experimental materials, consideration of how materials currently in the process of publication could be modified and, most essentially, consideration of how more principled, research-informed materials could be developed, published, marketed and sold at a profit.

I would recommend acceptance that no global course is ever going to be able to meet the needs and wants of all the teachers and learners who use it and that any global course will need local adaptation if it is to be successful in helping learners to develop communicative competence. To aid successful adaptation, choices of texts, activities, illustrations and pedagogic approaches could be offered and suggestions could be given to teachers and learners to help them to personalise, localise and supplement the materials.

I would recommend the development of blended materials which offer a coherent combination of paper, multi-media and digital materials to provide a menu of texts and activities for teachers and 
learners to choose from (Tomlinson \& Whittaker, 2010; Tomlinson, forthcoming). These materials would form the basis of courses which combine teacher supported classroom activities, learner-learner interaction in and out of class and individualised learner experience at home. Such materials could achieve the rich exposure to language in use, the recycling, the relevance, the meaningfulness, the cognitive and affective engagement and the opportunities for purposeful use recommended by second language acquisition research (Tomlinson \& Masuhara, 2018, forthcoming).

I would recommend acceptance that no course of materials can ever be enough and that learners need help in taking advantage of opportunities for language learning outside the course and outside the classroom. There could be units in the material which make learners aware of all the things they could do to exploit opportunities for language experience with other learners, with proficient users of the target language in their areas and on the web, through social media, from reading newspapers, magazines and books, from television, from the cinema, from talking to themselves etc. And each unit of material could end with suggestions for specific follow up activities outside the classroom. See Barker (2010), Pinnard (2016) and Tomlinson (2014a) for suggestions for out of class opportunities for language learning.

I would recommend sending publishing managers, editors and writers to conferences not to just stand by their stands in the Exhibition to help sell books but to give and to listen to presentations in order to find out about recent developments in the theory and practice of language learning and teaching.

I would recommend having regular in-house workshops (sometimes with a guest presenter from the academic or teaching world) in which publishing staff and writers at all levels discuss current issues in language learning and language learning materials.

I would recommend articulating research-informed principles for use in creating criteria for the development and evaluation of materials and ensuring that these criteria are given at least equal weighting with the curriculum and with the examination syllabus when developing new materials for publication.

I would recommend developing resources capable of responding to requests for tailor made courses from institutions, companies and governments who find that global coursebooks are not able to meet the needs and wants of their particular learners. Clients could specify their requirements for the objectives, syllabus, topic contents and methodology of the materials, the publisher could make recommendations for modification, decisions could be taken and localised learner specific materials could be developed.

I would recommend forming a consortium with a number of universities in different countries with a view to conducting joint research on materials development. Such a consortium could provide the funding and the expertise to resource the development, trialling and evaluation of experimental language learning materials and could lead to a major breakthrough in which principled, research-informed materials endorsed by renowned universities make both a profit and a positive impact on language learning. 


\section{My Recommendations to Ministries of Education}

I would recommend including experts on second language acquisition when making decisions about which textbooks to adopt and what resources to allocate to schools.

I would recommend allocating funds and expertise to the provision of out of class selflearning materials (Cooker, 2008, 2010 ) such as extensive readers, internet contact with other learners, supplementary smartphone materials (Tomlinson, forthcoming) in order to ensure experience of authentic communication.

I would recommend abandoning global coursebooks from overseas publishers and replacing them with locally developed materials with the potential to achieve greater relevance, meaningfulness and engagement for your learners.

I would recommend training and utilising local teachers as materials developers to design, pilot and produce language learning materials relevant to the experience and needs of local learners.

\section{My Recommendations to Materials Developers}

I would recommend finding out as much as possible about second language acquisition and theory and then combining this knowledge with classroom experience and observation in order to develop principle-driven criteria for the development and evaluation of new materials (Tomlinson, 2013a; Tomlinson \& Masuhara, 2018).

\section{My Recommendations to Teachers}

I would recommend making small adaptations to all published materials in order to make them more relevant, meaningful and engaging for their learners (Bao, 2018; Tomlinson, 2018; Tomlinson \& Masuhara, 2018)

I would recommend finding out as much as possible about second language acquisition and theory and then combining this knowledge with classroom experience and observation in order to develop principle-driven criteria for the development and evaluation of new materials and for the adaptation and use of existing materials (Tomlinson, 2013a, Tomlinson \& Masuhara, 2018).

I would recommend conducting 'enquiries' with your learners in which you investigate the effects of different types of materials on their eventual ability to use the target language (e.g. direct teaching of grammar $\mathrm{v}$ learner discovery; closed questions $\mathrm{v}$ open questions; extensive reading $\mathrm{v}$ intensive reading).

\section{My Recommendations to Researchers}

I would recommend ensuring that your materials development research aims to make discoveries of potential significance for teachers and learners even if it is not possible to provide empirical evidence offering conclusive proof. In my view it is of greater value to discover possible tendencies in relation to the effects of types of material than to provide reliable proof of a phenomenon which is self-evident (e.g. that learners give a more accurate and fluent presentation if they prepare it first). 
I would recommend making your research findings accessible to teachers, publishers and learners as well as to academic colleagues.

Above all I would recommend forming consortia with universities and publishers in order to conduct longitudinal research on the effects of different types of language learning materials on their users' eventual ability to communicate accurately, fluently, appropriately and effectively. These would be very difficult research projects with huge problems in isolating variables and with little prospect of conclusive proof. However I think any tendencies discovered could be of great value to teachers, materials developers and publishers and could contribute to the progress I long to see.

\section{Conclusion}

Throughout my fifty five year career I have gained great pleasure and reward from writing materials and using them in the classroom. I have gained some pleasure, some reward and much frustration from writing materials for publication. I have gained pleasure and reward from adapting materials to make them more suitable and engaging for my learners and from observing other teachers who have achieved this for their learners. I have suffered considerable boredom and anger from observing hundreds of lessons throughout the world in which teachers have not been able or allowed to make their materials more suitable or engaging for their learners.

My pleasure and reward has come from experiencing learner engagement, motivation and momentum and from observing learning in action. My frustration has come from being restricted by the (sometimes understandable) prohibitions of officials, principles and publishers. My anger has come from observing learners being disengaged and demotivated by materials which lack relevance, meaningfulness and opportunities for engagement.

My answer is an acceptance that no materials can cater for every (or even any) learner and that all materials need adaptation. If materials were written to be adapted with menus of texts and activities to be selected from and suggestions to teachers for localisation and personalisation, if there was more focus in materials on meaning and engagement and less on formal accuracy, and if learners were assessed on their ability to understand and communicate, then there would be less frustration, boredom and anger and more pleasure and more reward for everybody involved.

\section{References}

Aitchison, J. (2013). How ELT publishing works (Kindle ed.). Oxford: ELT Teacher 2 Writer http://www.eltteacher2writer.co.uk/.

Amrani, F. (2011). The process of evaluation: A publisher's view. In B. Tomlinson (Ed.), Materials development in language teaching (2nd ed., pp. 267-295). Cambridge: Cambridge University Press.

Azarnoosh, M., Zeraatpishe, M. Faravani, A. \& Kargozari, H. R. (Eds.). (2016). Issues in materials development. Rotterdam: Sense.

Bao, D. (Ed.). (2018). Creativity and innovations in ELT materials development: Looking beyond the current design. Bristol: Multilingual Matters.

Barker, D. (2010). The role of unstructured learner interaction in the study of a foreign language. In S. Menon \& J. Lourdunathan (Eds.), Readings on ELT materials IV (pp. 50-70). Petaling Jaya, Pearson Malaysia. 
Block, D. (2017). Political economy in applied linguistics research. Language Teaching 50/1, 32-64.

Bolitho, R. (2008). Materials used in central and eastern Europe and the former Soviet Union. In B. Tomlinson (Ed.), English language learning materials: A critical review (pp. 2013-222). London. Continuum.

Bori, P. (2018). Language textbooks in the era of neoliberalism. New York: Routledge.

British Council. (2008). Teaching English: Course Books. London: http://www.teachingenglish.org.uk/talk/polls/course-boobs

Cooker, L. (2008). Self-access materials. In B. Tomlinson (Ed.), English language learning materials: A critical review (pp. 110-132). London: Continuum.

Cooker, L. (2010). Some self-access principles. Studies in Self-Access Learning, 1(1), 5-9.

Coyle, D., P. Hood \& D. Marsh (2010). Content and language integrated learning. Cambridge: Cambridge University Press.

Cunningsworth, A. (1984). Evaluating and selecting EFL teaching material. London: Heinemann.

Ellis, R. \& Tomlinson, B. (1973). English through situations. Lusaka: Longman Zambia.

Fenner, A. N. \& Nordal Pedersen, G. (1999). Search 10. Oslo: Gyldendal.

Freeman, D. (2014). Reading comprehension questions: The distribution of different types in global EFL textbooks. In N. Harwood (Ed.), English Language Teaching Textbooks: Content, Consumption, Production (pp. 72-110). Basingstoke: Palgrave Macmillan.

Garton, S. \& Graves, K. (Eds.). (2014). International perspectives on materials in ELT. Basingstoke: Palgrave Macmillan.

Graves, K. (2019). Recent books on language materials development and analysis. ELT Journal, 73 (3), $337-354$.

Gray, J. (2012). Introduction. In J. Gray (Ed.), Critical perspectives on language teaching materials (pp. 1-16). London: Palgrave Macmillan.

Harwood, N. (Ed.). (2010a). Materials in ELT: theory and practice. Cambridge: Cambridge University Press.

Harwood, N. (Ed.). (2014). English language teaching textbooks: Content, consumption, production. Basingstoke: Palgrave: MacMillan.

Hidalgo, A. C., Hall, D. \& Jacobs, G. M. (Eds.). (1995). Getting started: materials writers on materials writing. Singapore: SEAMEO Language Centre.

Holborow, M. (2015). Language and neoliberalism. London: Routledge.

Maley, A. (2016). 'More Research is Needed' - A Mantra Too Far? Humanising Language Teaching, 18 (3), http://old.hltmag.co.uk/jun16/mart01.htm

Maley, A. \& Tomlinson, B. (Eds.). (2017). Authenticity in materials development for language learning. Newcastle: Cambridge Scholars.

Masuhara, H., Haan, M., Yi, Y. \& Tomlinson, B. (2008). Adult EFL courses. ELT Journal. 62 (3), $294-312$.

Masuhara, H., Tomlinson, B. \& Mishan, F. (Eds.). (2016). Practice and theory for materials development in language learning. Newcastle: Cambridge Scholars.

McDonough, J., Shaw, C. \& Masuhara, H. (2013). Materials and methods in ELT: a teacher's guide (3rd ed.). London: Blackwell.

McGrath, I. (2002). Materials evaluation and design for language teaching. Edinburgh: Edinburgh University Press.

McGrath, I. (2013). Teaching materials and the roles of EFL/ESL teachers: Practice and theory. London: Bloomsbury.

McGrath, I. (2016). Materials evaluation and design for language teaching (2 ${ }^{\text {nd }}$ ed.). Edinburgh: Edinburgh University Press. 
Mishan, F. \& Timmis, I. (2015). Materials development for TESOL. Edinburgh: Edinburgh University Press.

Moskowitch, G. (1978). Caring and sharing in the foreign language class: A sourcebook on humanistic techniques. Boston, Mass.:Heinle and Heinle.

Mukundan, J. (Ed.). (2003). Readings on ELT material. Sedang: Universiti Putra Malaysia Press.

Mukundan, J. (Ed.). (2008). Readings on ELT materials III. Petaling Jaya: Pearson Malaysia. On Target. (1995). Windhoek: Gamsburg Macmillan.

Piccardo, E. \& North, B. (2019). The action-oriented approach: A dynamic vision of language education. Bristol: Multilingual Matters.

Pinnard, L. (2016). Looking outward: using learning materials to help learners harness out of-class learning opportunities. Innovation in Language Learning and Teaching. Special Issue. B. Tomlinson (Guest Editor). 10 (2), 133-143.

Popovici, R. \& Bolitho, R. (2003). Personal and professional development through writing: The Romanian textbook project. In B. Tomlinson (Ed.), Developing materials for language teaching (pp. 505-17). London: Continuum.

Prowse, P. (2011). How writers write: testimony from authors. In B.Tomlinson (Ed.), Materials development in language teaching ( $2^{\text {nd }}$ ed., pp. 151-73). Cambridge: Cambridge University Press.

Renandya, W. A. (Ed.). (2003). Methodology and materials design in language teaching: current perceptions and practises and their implications. Singapore: RELC.

Richards, J. (1978). Understanding second and foreign language learning : Issues and approaches. Harlow: Longman.

Risager, K. (2018). Representations of the world in language textbooks. Bristol: Multilingual

Saw, T. S. (2016). Evaluating the external materials used for cultural elements in ELT course-books through teacher perception of teaching and learning. Unpublished $\mathrm{PhD}$ thesis. University of Essex.

Sheldon, L. E. (Ed.). (1987). ELT textbooks and materials: problems in evaluation and development. ELT documents 126. London: Modern English Publications and the British Council.

Singapore Wala, D. A. (2003). Publishing a coursebook: Completing the materials development circle. In B. Tomlinson (Ed.), Developing materials for language teaching ( $1^{\text {st }}$ ed., pp. 141-161). London: Continuum.

Singapore Wala, D. A. (2013). Publishing a coursebook: The role of feedback. In B. Tomlinson (Ed.), Developing materials for language teaching (2nd ed., pp. 63-87). London: Bloomsbury.

Tomlinson, B. (Ed.). (1981). Talking to learn. Port Vila: Govt. of Vanuatu.

Tomlinson, B. (1990). Managing change in Indonesian high schools. ELT Journal 44(1), 25-37.

Tomlinson, B. (1994). Materials for TPR. Folio 1 (2), 8-10.

Tomlinson, B. (1995). Work in progress: textbook projects, Folio, 2 (2), 26-31.

Tomlinson, B. (Ed.). (1998a). Materials development in language teaching. Cambridge: Cambridge University Press.

Tomlinson, B. (2001). Materials development. In R. Carter \& D. Nunan (Eds.), The Cambridge guide to TESOL (pp. 66-71). Cambridge: Cambridge University Press.

Tomlinson, B. (Ed.). (2003). Developing materials for language teaching. London: Continuum Press.

Tomlinson, B. (Ed.). (2008a). English language teaching materials: a critical review. London: Continuum.

Tomlinson, B. (2010a). Principles and procedures of materials development. In N. Harwood (Ed.), Materials in ELT: theory and practice (pp. 81-108).Cambridge: Cambridge University Press.

Tomlinson, B. (2010b). What do teachers think about EFL coursebooks? Modern English Teacher 19 (4), 5-9. 
Tomlinson, B. (Ed.). (2011a). Materials development in language teaching (2nd ed.). Cambridge: Cambridge University Press.

Tomlinson, B. (2011b). Principled procedures in materials development. In B. Tomlinson (Ed.), Materials development in language teaching (2nd ed., pp. 1-31). Cambridge: Cambridge University Press.

Tomlinson, B. (2012). Materials development for language learning and teaching. Language Teaching: Surveys and Studies 45 (2), 143-179.

Tomlinson, B. (Ed.) (2013a). Developing Materials for Language Teaching (2 ${ }^{\text {nd }}$ ed.). London: Continuum Press.

Tomlinson, B. (2013b). Developing principled frameworks for materials development. In B. Tomlinson (Ed.), Developing materials for language teaching ( $\left.2^{\text {nd }} \mathrm{ed} ., \mathrm{pp} .95-118\right)$. London: Continuum Press.

Tomlinson, B. (Ed.). (2013c). Applied linguistics and materials development. London: Continuum.

Tomlinson, B. (2014a). Looking out for English. Folio 16 (1), 5-8.

Tomlinson, B. (2014b). Teacher growth through materials development. The European Journal of Applied Linguistics and TEFL. Special Issue. A. Maley (Ed.), 3 (2), 89-106.

Tomlinson, B. (Ed.). (2016). SLA research and materials development for language learning. New York: Routledge.

Tomlinson, B. (2018). Making typical coursebook activities more beneficial for the learner. In D. Bao (Ed.), Creativity and innovations in ELT materials development: Looking beyond the current design (pp. 21-34). Bristol: Multilingual Matters.

Tomlinson, B. (2019). Evaluating, adapting and developing materials for EIL learners. Malang: TEFLIN.

Tomlinson, B. (forthcoming). Blended learning: The future of ELT?' In J. I. Liontas (Ed.), TESOL encyclopedia of English language teaching. Hoboken, NJ: Wiley.

Tomlinson, B., Dat, B, Masuhara, H. \&Rubdy, R. (2001). ELT courses for adults. ELT Journal 55 (1), 80-101.

Tomlinson, B. \& Masuhara, H. (Eds.). (2010). Research for materials development in language learning: evidence for best practice. London: Continuum.

Tomlinson, B. \&Masuhara, H. Review of Adult ELT Textbooks. ELT Journal. 67/2, 233-249.

Tomlinson, B. \&Masuhara, H. (2018). The complete guide to the theory and practice of materials development for language learning. Hoboken: Wiley.

Tomlinson, B. \&Masuhara, H. (forthcoming). SLA applied: Applying second language acquisition research and theory to language learning. Cambridge: Cambridge University Press.

Tomlinson, B. \& Whittaker, C. (2010). (Eds.). Case studies of blended learning courses. London: British Council.

Zemach, D. (2018). Sausage and the law: How textbooks are made. IATEFL Online 2018. https://www.teachingenglish.org.uk/article/sausage-law-how-textbooks-are-made - retrieved 7/10/2019. 